Hasanuddin Economics and Business Review 04:2 (2020) 37-43

\title{
The Effect of Financial Literation on Students's Personal Financial Planning in Malang (Case Study on Pesantren Luhur Malang and Pesantren Al-Barakah Malang)
}

\author{
Desy Erlanda Pratasaria , Grisvia Agustin ${ }^{\mathrm{a}, *}$ \\ ${ }^{a}$ Ekonomi Pembangunan Universitas Negeri Malang Indonesia
}

\begin{abstract}
Financial literacy is very important because it is needed for financial planning so that people can manage their finances more optimally. However, according to the FSA, Indonesia has a low level of financial literacy, so there is a need for research on differences in financial planning in Pesantren Luhur Malang which obtain financial literacy studies from Kitab Kuning and halaqah (a seminar of scientific study) with financial planning in Pesantren Al-Barakah Malang which gain financial literacy from Kitab Kuning only. This study aims to determine the effect of financial literacy on the financial planning of students of Pesantren Luhur Malang and students of Pesantren Al-Barakah Malang, as well as differences in financial literacy and financial planning between students Pesantren Luhur Malang and students of Pesantren Al-Barakah Malang. This study uses a descriptive quantitative approach, with two variables financial literacy and financial planning, using simple linear regression analysis and independentsample t-test. Sampling using purposive sampling with a total sample of 52 students consisting of 26 students of Pesantren Luhur Malang and 26 students of Pesantren Al-Barakah Malang. Based on data analysis, are known that (1) financial literacy has an effect on financial planning in students of Pesantren Luhur Malang and students Pesantren Al-Barakah Malang (2) there is a difference between the financial literacy of students of Pesantren Luhur Malang and students of Pesantren Al-Barakah Malang. (3) there are differences in the financial planning of students Pesantren Luhur Malang and students Pesantren Al-Barakah Malang.
\end{abstract}

Keywords: financial literacy, personal financial planning, students

\section{INTRODUCTION}

The National Financial Literacy Strategy Program is launched by the Otoritas Jasa Keuangan (OJK)/Financial Services Authority and the Asosiasi Lembaga Jasa Keuangan (LJK)/ Association of Financial Services Institutions with a mission to carry out education in the field of finance aiming at Indonesian people to be able to manage good finance. The results of a national survey done by OJK in 2013 showed that Indonesian level of financial participation was relatively low with the financial literacy index $21.84 \%$ and then increased in 2016 with the financial literacy index $29.66 \%$ Otoritas Jasa Keuangan (2016), the increase in the level of financial literacy hopefully could help Indonesian make better financial decisions.

The knowledge and understanding of personal finance are needed by each people to be able to make the right decisions in their finances. Therefore, in this case, financial literacy is

\footnotetext{
* Author in correspondence,

Email address: grisvia.agustin.fe@um.ac.id (Grisvia Agustin)
}

absolutely necessary for someone to be able to optimally use the right instruments and financial products. Financial literacy will be reached if someone has a set of skills and abilities that make him able to utilize existing resources to achieve a goal.

Financial planning reflects someone's current state and how he plans to further develop and build his capacity to manage his financial needs. Financial difficulties are not could only be seen from one's income (the low income), but can also occur in financial management such as mistakes in using credit and lack of financial planning. This research focuses on students, which being a student who learns in pesantren (Islamic boarding school) is the time - the first time for most of them, be responsible for financial decisions they make, without the control of the parents (Septiana, 2017). It is the same case with the one generally happens in people's daily life, with students' unlimited needs but limited money given by their parents and their diverse origin background, which will influence their financial management style. Those influences can bring both positive and negative effects. The positive influence can be seen from their independence of financial management. While the negative influence is closely related to the consumption expenditure that has been chosen (Septiana, 2017). 
The object of this research was students who were college students in Malang, who live Pesantren Luhur Malang and Pesantren Al-Barakah Malang, which aims at measuring financial literacy levels on students' personal financial planning through questionnaires. The students with financial studies from Kitab Kuning and halaqah (a seminar of scientific studies) and in Pesantren Al-Barakah Malang because students get financial studies from Kitab Kuning only. The Kitab Kuning/yellow book is a term used by some people to refer to Arabic books. Since ancient times, these Arabic books have been used by many Islamic boarding schools as study material for students.

This study aims at determining the effect of financial literacy on the financial planning of students Pesantren Luhur Malang and students Pesantren Al-Barakah Malang, as well as differences in financial literacy and financial planning between students Pesantren Luhur Malang and students Pesantren AlBarakah Malang. And the problem formulations in this study are:

1. How does financial literacy influence the personal financial planning of students Pesantren Luhur Malang and students Pesantren Al-Barakah Malang?

2. How is the difference between the financial literacy of students of Pesantren Luhur Malang and students Pesantren Al-Barakah Malang?

3. What is the difference between personal financial planning between students Pesantren Luhur Malang and students Pesantren Al-Barakah Malang?

\section{LITERATURE REVIEW}

\subsection{Financial Literacy}

Financial literacy is a process of increasing public knowledge, skills, and confidence in financial institutions, financial products, and services that have been outlined in index size parameters aimed at improving the quality of decision making and financial management in order to achieve goals (Otoritas Jasa Keuangan, 2013). One's knowledge helps in decisions making and choosing financial products that can optimize their financial decisions. Therefore, financial literacy becomes a very important knowledge that should be owned by everyone so that people could avoid making mistakes in making their financial decisions (Margaretha and Pambudhi, 2015).

Financial literacy is the one's or community's knowledge in managing their finances to achieve healthy personal finances (Warsono, 2010). According to the Draft Regulation of the Financial Services Authority No 76 / POJK.07 / 2016 regarding the increase of financial literacy and financial inclusion in the financial services sector for the public that financial literacy is knowledge, beliefs, and skills that affect attitudes and behaviors to improve the quality of decision making and financial management in order to achieve well-being.

The level of financial literacy in the students of Pesantren Luhur Malang and students of Pesantren Al-Barakah Malang is measured through a questionnaire consists of questions that refer to Robb and Woodyard (2011) which contains financial knowledge including compound interest, inflation, bond prices, divisions (calculations), mortgage (credit), diversification, the time value of money, and the risk of stocks or bonds.

\subsection{Financial Planning}

Financial planning is an art in financial management carried out by individuals or families to achieve effective, efficient, and beneficial goals, to achieve the prosperity of life. In general, the activities carried out are processes in managing income to achieve financial goals such as the desire to have a marriage fund, childbirth funds, etc.(Otoritas Jasa Keuangan, 2013).

Every person must have the potential in realizing their financial independence, in order to be realized it requires financial planning. Financial planning is a process for individuals who are trying to carry out their financial goals by means of the implementation and development of comprehensive plans, good financial planning will produce a plan that can facilitate a person in his financial goals, such thing is like a blueprint that can show where individual financial condition running (Ghozie, 2019).

Financial planning is very important because it is the process of achieving future goals for a prosperous and happy future through financial planning (Dorimulu, 2003). Personal financial planning is the process of managing individual finances to achieve personal economic satisfaction (Kapoor et al., 2014). Personal financial planning is a process for managing money to achieve personal economic satisfaction. Both economic satisfaction and personal satisfaction are the results of the personal financial planning process (Kapoor et al., 2014).

Good financial planning can make it easier for someone to achieve their financial goals. The purpose of financial planning is how someone can make his expenses more effective or for things that are prioritized. Here are some examples of financial plans for each goal. The level of financial planning in Pesantren Luhur Malang and Pesantren Al-Barakah Malang was measured through a questionnaire containing statements about personal financial planning that refer to the research of Boon et al. (2011) which contains financial planning, managing liabilities, managing insurance, managing investments, managing pensions and inheritance planning.

\section{RESEARCH METHOD}

This study aims at determining the effect of financial literacy on the financial planning of students of Pesantren Luhur Malang and students of Pesantren Al-Barakah Malang, as well as differences in financial literacy and financial planning between Pesantren Luhur Malang and Pesantren Al-Barakah Malang.

This study uses a descriptive quantitative approach, with two variables - financial literacy as the dependent variable (X) and financial planning as independent variables (Y), using simple linear regression analysis and independent-sample t-test. Sampling uses purposive sampling which is to assign respondents to be sampled based on certain criteria with a total sample 
of 52 students consisting of 26 students Pesantren Luhur and 26 students of Pesantren Al-Barakah Malang.

Data collection techniques using a questionnaire with Gudman time and Likert scale. The feasibility test uses a validity test and a reliability test. The classic assumption test uses the normality test, the auto-correlation test, and the heteroscedasticity test and then continues with the hypothesis test.

\section{ANALYSIS}

\subsection{Financial Literacy}

Data description regarding financial literacy is seen from 8 item items or tests in the questionnaire given to 52 respondents, 26 respondents from Pesantren Luhur Malang and 26 respondents from Pesantren Al-Barakah Malang 2016, by classifying into 4 classes, 18 respondents have financial literacy. very high, as many as 12 respondents have high financial literacy, as many as 12 respondents have moderate financial literacy and as many as 10 respondents have poor financial literacy.

\subsection{Financial Planning}

Data description regarding financial planning can be seen from the 20 statements in the questionnaire given to 52 respondents namely 26 respondents from Pesantren Luhur Malang and 26 respondents from Pesantren Al-Barakah Malang class of 2016, how to classify into 4 classes, 10 respondents have very high financial planning, 12 respondents have high financial planning, 30 respondents have moderate financial planning and 0 respondents have poor financial planning.

\subsection{Classical Assumption Test}

\subsubsection{Normality Test}

The normality test aims to test in the regression model whether the independent and dependent variables have a normal distribution or not. A good regression model is normal or nearnormal data distribution (Ghozali, 2009). In order to know the symptoms of normality can be seen using a pp-plot graph.

\subsubsection{Autocorrelation Test}

The autocorrelation test aims to test in the linear regression model whether there is no correlation between confounding errors in the $\mathrm{t}-1$ period or the previous period. This test uses the Durbin Waston (Ghozali, 2009). The autocorrelation test results in Table 1.

Table 1: Add caption

\begin{tabular}{llrrr}
\hline $\mathrm{R}$ & $\mathrm{R}$ & $\begin{array}{l}\text { Adjusted } \\
\text { R Square }\end{array}$ & $\begin{array}{l}\text { Std. Er- } \\
\text { ror of the } \\
\text { Estimate }\end{array}$ & $\begin{array}{l}\text { Durbin- } \\
\text { Watson }\end{array}$ \\
\hline 0.5 & 0.247 & 0.232 & 12.104 & 1.35 \\
\hline Source: & Research computation &
\end{tabular}

Based on Table 1 above the DW value is 1.350 using a significant value of 0.05 , with a total sample of 52 (n) and the

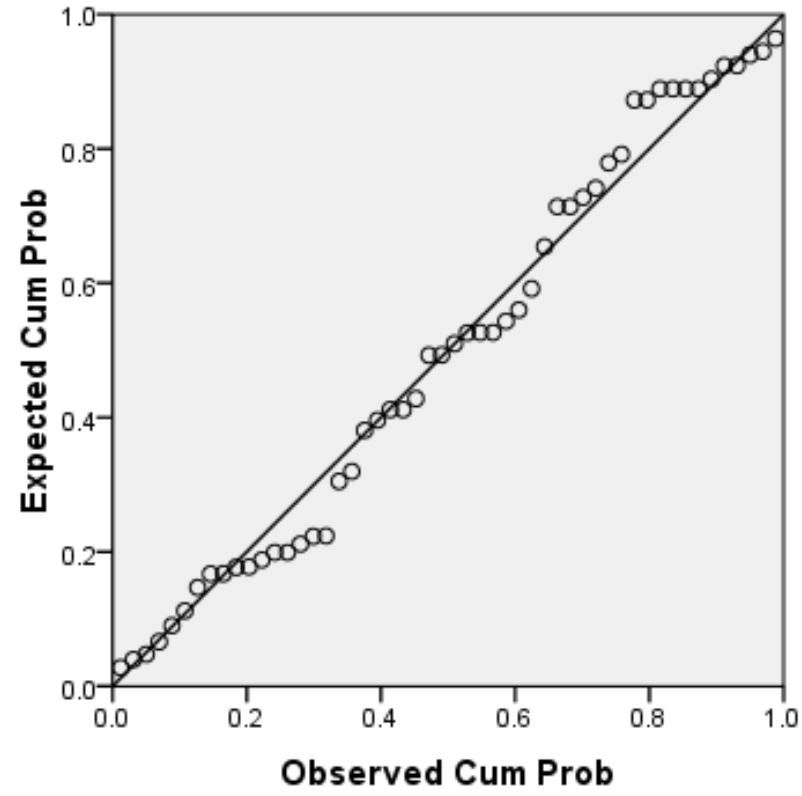

Figure 1: Normal P-P Plot of Regression Standardized Residual

number of independent variables $1(\mathrm{~K}=1)$. In the DW table the $\mathrm{dU}$ value is 1.5917. Because the DW value is smaller than the dU limit and more than $(4-\mathrm{dU})=4-1.5917=2.4083$. so it can be concluded that there is autocorrelation.

\subsubsection{Heteroscedasticity Test}

The heteroscedasticity test aims to test in the regression model that there is an inequality of variance from residuals or observations to other observations. the way to find out whether heteroscedasticity occurs or not in this model testing is done by the Glejser test that is by way of regressing the independent variable to the absolute residual value on the basis of the decision making is if the significance value is less than 0.05 then heteroscedasticity occurs if the significance is more than 0.05 then it does not heteroscedasticity occurs (Ghozali, 2009). Heteroscedasticity test results in the Table 2.

Table 2: The Result of Heteroscedasticity Test

\begin{tabular}{|c|c|c|c|c|}
\hline \multirow[t]{2}{*}{ Model } & \multicolumn{2}{|c|}{$\begin{array}{l}\text { Unstandardized } \\
\text { Coefficients }\end{array}$} & \multirow[t]{2}{*}{$\mathrm{t}$} & \multirow[t]{2}{*}{ Sig. } \\
\hline & B & $\begin{array}{l}\text { Std. Er- } \\
\text { ror }\end{array}$ & & \\
\hline (Constant) & 4.69 & 1.710 & 2.742 & 0.08 \\
\hline skor_X & 1.061 & 0.303 & 3.498 & 0.01 \\
\hline
\end{tabular}

Heteroscedasticity test results from Table 2, the significance of the independent variable or $\mathrm{X}$ shows 0.001 of the significance standard value of 0.05 . So it can be concluded that there was a heteroscedasticity problem. 


\subsection{Ordinary Least Square}

The analysis in this study uses simple linear regression because it is used to determine the relationship between independent variables, namely financial literacy $(\mathrm{X})$ and the dependent variable, namely financial planning (Y) (Gujarati, 2009). The concise results of a simple linear regression test can be seen in Table 3.

Table 3: The Result of Simple Linier Regression Test

\begin{tabular}{|c|c|c|c|c|c|}
\hline \multirow[t]{2}{*}{ Model } & \multicolumn{3}{|c|}{ Unstandard. Standard. } & \multirow[t]{2}{*}{$\mathrm{t}$} & \multirow[t]{2}{*}{ Sig. } \\
\hline & B & Std. Error & Beta & & \\
\hline (Constant) & 50.168 & 3.488 & & 14.38 & 0.000 \\
\hline $\begin{array}{l}\text { Financial } \\
\text { literacy }\end{array}$ & 2.507 & 0.619 & 0.497 & 4.052 & 0.000 \\
\hline
\end{tabular}

From Table 3 we can find out the simple linear regression equation as follows:

$$
Y=50.168+2.507 X
$$

Based on the above equation can be concluded that if the financial literacy increase of 1 unit, it will increase financial planning by 2,507 .

\subsubsection{Financial Literacy}

The results of the independent sample t-test regarding financial literacy between Pesantren Luhur Malang and Pesantren Al-Barakah Malang can be seen in the Table 4.

Table 4: The Result of Average Financial Literacy

\begin{tabular}{lcccc}
\hline Pesantren & $\mathrm{N}$ & Mean & $\begin{array}{l}\text { Std. } \\
\text { Devi- } \\
\text { ation }\end{array}$ & $\begin{array}{l}\text { Std. } \\
\text { Error } \\
\text { Mean }\end{array}$ \\
\hline $\begin{array}{l}\text { Pesantren } \\
\begin{array}{l}\text { Luhur } \\
\text { Pesantren Al- } \\
\text { Barakah }\end{array}\end{array}$ & 26 & 6.88 & 1.681 & 0.33 \\
\hline
\end{tabular}

Source: Research computation

Table 4 shows the data of financial literacy results for respondents in students of Pesantren Luhur Malang as many as 26 while the respondents of students of Pesantren Al-Barakah Malang were also as many as 26 respondents. The average value of financial literacy for students of Pesantren Luhur Malang was 6.88 and students of Pesantren Al-Barakah Malang were 3.00. It was concluded that there were differences in the average financial literacy between students of Pesantren Luhur Malang and students of Pesantren Al-Barakah Malang.

Table 4 shows, the standard error value of financial literacy means students of Pesantren Luhur Malang and students of Pesantren Al-Barakah Malang are either small or not diverse. test and can be seen in the Table 5 .
Based on Table 5, the output of the test results above is known that the significant value on Equal Variances Assumed is $0.137>0.05$, it can be interpreted that the data variance between students of Pesantren Luhur Malang and students of Pesantren Al-Barakah Malang is the same. Based on the independent table t-test sample known significant values. (2 tailed) of $0,000<$ 0.05 , then the basis for decision making in the independent sample t test concluded that $H_{o}$ was rejected and $H_{a}$ was accepted. Thus it can be concluded that there is a significant (real) difference between the average results of financial literacy between students of Pesantren Luhur Malang and students of Pesantren Al-Barakah Malang.

\subsubsection{Financial Planning}

The results of the independent sample t-test regarding financial planning between the students of Pesantren Luhur Malang and students of Pesantren Al-Barakah Malang can be seen in the Table 6.

Table 6 shows the data of financial planning results for students of Pesantren Luhur respondents as many as 26 while students of Al-Barakah respondents were also 26 respondents. The average value of financial planning for students of Pesantren Luhur Malang was 68.54, while for students of Pesantren AlBarakah Malang students was 56.58. Thus, it can be concluded that there are differences in average financial literacy between students of Pesantren Luhur Malang and students of Pesantren Al-Barakah Malang.

In the table above shows that the standard mean error value of financial planning at students of Pesantren Luhur Malang is higher than students of Pesantren Al-Barakah Malang. To see the difference between the influence of financial planning between students of Pesantren Luhur Malang and students of Pesantren Al-Barakah Malang, in this case the independent sample t-test was conducted in Table 7.

Table 7 shows that the output of the test results above is known that the significant value on Equal Variances Assumed is $0,000<0.05$, it can be interpreted that the data variance between students of Pesantren Luhur Malang and students of Pesantren Al-Barakah Malang is not the same. Based on the pvalue which is $0.001<0.05$, then the basis for decision making in the independent sample t test concluded that $H_{o}$ was rejected and $H_{a}$ was accepted. Thus it can be concluded that there is a significant (real) difference between the average results of financial planning between students of Pesantren Luhur Malang and students of Pesantren Al-Barakah Malang.

Average results of 11,962 . This value shows the difference between the average financial planning of students of Pesantren Luhur Malang and students of Pesantren Al-Barakah Malang or $68.54-56.58=11.96$ and the difference is 4.972 to 18.951 . The results of the $t$ arithmetic are positive indicating that the results of the students of Pesantren Luhur Malang have a higher level of financial planning compared to the students of Pesantren AlBarakah Malang.

\subsection{Hypothesis Testing}

Based on data analysis, there are three hypotheses that will be tested in this research regarding the financial literacy of per- 
Table 5: The Result of Financial Literacy Independent t-Test

\begin{tabular}{|c|c|c|c|c|c|c|c|c|}
\hline & \multicolumn{2}{|c|}{ Levene's Test } & \multicolumn{6}{|c|}{ t-test for Equality of Means } \\
\hline & \multirow[t]{2}{*}{$\mathrm{F}$} & \multirow[t]{2}{*}{ Sig } & \multirow[t]{2}{*}{$\mathrm{t}$} & \multirow[t]{2}{*}{ df } & \multirow[t]{2}{*}{$\begin{array}{l}\text { Sig. } \\
(2- \\
\text { tailed })\end{array}$} & \multirow[t]{2}{*}{$\begin{array}{l}\text { Mean } \\
\text { Diff. }\end{array}$} & \multirow{2}{*}{$\begin{array}{l}\text { Std. } \\
\text { Er- } \\
\text { ror } \\
\text { Diff. }\end{array}$} & $\begin{array}{l}95 \% \text { Conf. } \\
\text { Interval of } \\
\text { the Diff. }\end{array}$ \\
\hline & & & & & & & & Lower Upper \\
\hline $\begin{array}{l}\text { Equal variances } \\
\text { assumed }\end{array}$ & 2.29 & 0.14 & 7.25 & 50 & 0 & 3.885 & 0.536 & 4.961 \\
\hline $\begin{array}{l}\text { Equal variances } \\
\text { not assumed }\end{array}$ & & & 7.25 & 47.21 & 0 & 3.885 & 0.536 & 4.963 \\
\hline
\end{tabular}

Source: Research computation

Table 6: The Result of Average Financial Planning

\begin{tabular}{lcccc}
\hline Pesantren & $\mathrm{N}$ & Mean & $\begin{array}{l}\text { Std. } \\
\text { Devi- } \\
\text { ation }\end{array}$ & $\begin{array}{l}\text { Std. } \\
\text { Error } \\
\text { Mean }\end{array}$ \\
\hline $\begin{array}{l}\text { Pesantren } \\
\begin{array}{l}\text { Luhur } \\
\text { Pesantren Al- } \\
\text { Barakah }\end{array}\end{array}$ & 26 & 68.54 & 15.379 & 3.016 \\
\hline
\end{tabular}

Source: Research computation

sonal financial planning students of Pesantren Luhur Malang and students of Pesantren Al-Barakah Malang as follows.

Table 8 proving this hypothesis means that the level of financial literacy has a positive and significant influence on personal financial planning owned by students of Pesantren Luhur Malang and students of Pesantren Al-Barakah Malang.

From the analysis it was found that the $\mathrm{R}$ square value of financial literacy on financial planning shows 0.247 which means that students' understanding of financial literacy contributes and influences the financial planning of students, $H_{O}$ which says there is no implication between financial literacy variables on financial planning is rejected, while $H_{a}$ is accepted because the value of $\mathrm{R}$ square which shows the number 0.247 which means financial literacy has an impact on personal financial planning of students.

From Table 9 it is known that the value of is 4,052 and it's p-value is 0.000 then $H_{o}$ is rejected $H_{a}$ is accepted. Thus it can be concluded that financial literacy has a significant influence on financial planning students of Pesantren Luhur Malang and students of Pesantren Al-Barakah Malang 2016.

\section{DISCUSSION}

The effect of financial literacy on financial planning based on the level of financial literacy shows that someone with high financial literacy can make financial planning than someone who has moderate or low financial literacy. This is strengthened by research conducted by (Boon et al., 2011) showing that in various countries that lack financial literacy affects individual decisions in financial planning.
This research focuses on students, which is a student who learns in pesantren is the time - the first time for most of them, be responsible for financial decisions they make, without the control of the parents. It is a very crucial time because in this period they should be able to learn how to manage their finances independently and should be responsible for any decisions they made for their finances (Septiana, 2017).

The research chose Pesantrens in Malang as the location of the research because Malang is known as an education city with lots of colleges and pesantren. The object of this research is students with the status of students in Malang because they get two kinds of education, formal and non-formal. The respondents in this research are students in Pesantren Luhur Malang and students in Pesantren Al-Barakah Malang. This research measures the level of financial literacy on the personal financial planning of students through questionnaires. The reason for choosing Pesantren Luhur Malang as the object of the research because of students there get financial studies from Kitab Kuning and halaqah (a seminar of scientific studies) and choosing Pesantren Al-Barakah Malang because students there are given financial studies from Kitab Kuning only.

Moreover, the reason for choosing this study is because this research has never been done before. The understanding of financial literacy obtained by students of Pesantren Luhur Malang originated from the results of the routine activities of the students in every Friday afternoon studying Kitab Kof 'Asybah Wan Nadhair' written by Syech Imam Jalaluddin As Suyuthi, taught directly by Ustadz Busro Karim, discussing Islamic fiqh including the discussion of Islamic finance such as accounts payable, inheritance, rent, sale and purchase and so forth.

Not only from the study of Kitab Kuning on Friday afternoon, but they also get the understanding of finance during halaqah, but the activity also carried out by all students at the end of the dawn prayer. Halaqah served discussion in various fields of science, for discussions about finance are often conveyed, in this activity students of Pesantren Luhur Malang themselves are presenters and subsequently clarified by the economic discussion team and in these activities, there are also discussions so as to make students of Pesantren Luhur Malang who not aware about finance can ask questions and those who know about finance can add, thus making it easier for students to understand about finance.

Financial understanding obtained by students in Pesantren 
Table 7: The Result of Financial Planning Independent t-Test

\begin{tabular}{|c|c|c|c|c|c|c|c|c|}
\hline & \multicolumn{2}{|c|}{ Levene's Test } & \multicolumn{6}{|c|}{ t-test for Equality of Means } \\
\hline & \multirow[t]{2}{*}{$\mathrm{F}$} & \multirow[t]{2}{*}{ Sig } & \multirow[t]{2}{*}{$\mathrm{t}$} & \multirow[t]{2}{*}{ df } & \multirow[t]{2}{*}{$\begin{array}{l}\text { Sig. } \\
(2- \\
\text { tailed })\end{array}$} & \multirow[t]{2}{*}{$\begin{array}{l}\text { Mean } \\
\text { Diff. }\end{array}$} & \multirow{2}{*}{$\begin{array}{l}\text { Std. } \\
\text { Er- } \\
\text { ror } \\
\text { Diff. }\end{array}$} & $\begin{array}{l}95 \% \text { Conf. } \\
\text { Interval of } \\
\text { the Diff. }\end{array}$ \\
\hline & & & & & & & & Lower Upper \\
\hline $\begin{array}{l}\text { Equal variances } \\
\text { assumed }\end{array}$ & 15.06 & 0 & 3.44 & 50 & 0.001 & 11.962 & 3.48 & 18.951 \\
\hline $\begin{array}{l}\text { Equal variances } \\
\text { not assumed }\end{array}$ & & & 3.44 & 39.92 & 0.001 & 11.962 & 3.48 & 18.995 \\
\hline
\end{tabular}

Source: Research computation

\begin{tabular}{llrr}
\multicolumn{4}{c}{ Table 8: The Result of Hypothesis Testing } \\
\hline $\mathrm{R}$ & $\mathrm{R}$ & $\begin{array}{l}\text { Adjusted } \\
\text { Square }\end{array}$ & $\begin{array}{l}\text { Std. Er- } \\
\text { R Square } \\
\text { ror the } \\
\text { Estimate }\end{array}$ \\
\hline 0.497 & 0.247 & 0.232 & 12.104 \\
\hline Source: & Research computation
\end{tabular}

Table 9: The Effect of Financial Literacy on Financial Planning

\begin{tabular}{|c|c|c|c|c|c|}
\hline \multirow[t]{2}{*}{ Model } & \multicolumn{3}{|c|}{$\begin{array}{l}\text { Unstandard. Standard. } \\
\text { Coeff. } \quad \text { Coeff. }\end{array}$} & \multirow[t]{2}{*}{$\mathrm{t}$} & \multirow[t]{2}{*}{ Sig. } \\
\hline & B & Std. Error & Beta & & \\
\hline (Constant) & 50.17 & 3.488 & & 14.38 & 0.00 \\
\hline $\begin{array}{l}\text { Financial } \\
\text { literacy }\end{array}$ & 2.507 & 0.619 & 0.497 & 4.052 & 0.00 \\
\hline
\end{tabular}

Source: Research computation

Al-Barakah Malang the study of the evening Kitab Kuning which was studied on Thursday night which discusses Islamic economic fiqh with the name of the book Fathul Qorib written by Syamsuddin Abu 'Abdillah Muhammad bin Qosim Al Ghozzi which was guided by Ustad Qomari in this book discusses Islamic economic jurisprudence, one of which discusses finance such as accounts payable, inheritance, rent, sale and purchase and so forth. In Pesantren Luhur Malang, a study of finance in a year is about 48 times, because the study is conducted once a week and taken 2 weeks off in a year. Whereas in less Pesantren Al-Barakah Malang around 42 times a year, because the study is done once a week and taken 2 months off for a year.

Financial literacy will be realized if an individual has a set of skills and abilities that make a person able to utilize existing resources to achieve a goal. Financial intelligence is not seen from how much money a person earns but from how much money is saved and how far the money works for someone. So that people who have financial intelligence, that is, if someone ages, the money they have can provide freedom, happiness, health, and a variety of life choices and vice versa, those who are not financially intelligent those who are getting older but who are also getting bigger bills that have to pay so that makes someone have to work harder to pay off their debts (Septiana,
2017).

Carpena et al. (2011) noted that there are three dimensions of financial literacy, namely calculation skills, an understanding of basic finance and attitudes towards financial decisions. Whereas Willis (2008) knowledge in the context of financial literacy includes knowledge, education, and information about finance and its sources, banking, deposits, credit, insurance, and taxes. Financial knowledge that is owned by someone then develops into financial skills, where financial skills themselves are defined as the ability to apply financial knowledge that has been owned in everyday life (Palameta et al., ????).

From the results of understanding financial literacy for students of Pesantren Luhur Malang respondents as many as 26 and students of Pesantren Al-Barakah Malang respondents as many as 26 respondents who measured through a questionnaire with 8 questions that refer to Robb and Woodyard (2011) which contains financial knowledge including compound interest, inflation, prices bonds, divisions (calculations), mortgages (credit), diversification, the time value of money and the risk of stocks or bonds.

The understanding of the financial literacy of students of Pesantren Luhur Malang is different from students of Pesantren Al-Barakah Malang and with the results of the financial literacy understanding of students of Pesantren Luhur Malang is higher than students of Pesantren Al-Barakah Malang. That is because the students of the sublime Pesantren their teaching are more focused on the Kitab Kuning so that teaching on Islamic economics fiqh chapter on finance is listed in the Kitab Kuning Asybah Wan Nadhair by Syech Imam Jalaluddin As Suyuthi and also scientific halaqah activities which often discuss finance with the financial system discussion therein so as to make the Luhur pesantren's students have a higher level of financial literacy compared to Al-Barakah Pesantren students in Malang, because focusing on Al-Barakah students is divided into two, namely learning the Kitab Kuning and memorizing the Qur'an.

The level of financial literacy is seen from the standard error of the mean financial literacy of students of Pesantren Luhur Malang and students of Pesantren Al-Barakah Malang which are either small or not diverse. The study of financial literacy was also obtained from the background of students studying in economics.

Financial planning is very important because, it is a process of achieving future goals for a prosperous and happy fu- 
ture through financial planning (Dorimulu, 2003). Financial planning reflects the current state of a person and how someone plans to further develop and build their capacity in managing financial needs because in everyday life humans are not free from planning to realize their ideals. Planning is a measuring tool in achieving the planned objectives. This is used as a measure of where one's financial position is at the moment. Is someone's financial position is more advanced or behind the plans that have been made (Akbar, 2019)?

Good financial planning can make it easier for someone to achieve their financial goals. The purpose of financial planning is how a person can make his expenses more effective or for things that are prioritized. In the measurement of planning in students of Pesantren Luhur Malang as many as 26 respondents and students of Pesantren al Barakah Malang as many as 20 respondents were carried out through a questionnaire with 20 statements that refer to the research of Boon et al. (2011) which contains about financial planning, managing liabilities, managing insurance, managing investments, managing pensions and inheritance planning.

The level of financial planning is chosen from the standard error value of mean financial planning at Al Luhur Malang Islamic Boarding School students. related to financial literacy, because the effect of financial literacy on financial planning based on the level of financial literacy shows that individuals with high financial literacy can make financial planning compared to a person's level of financial literacy is low or moderate.

\section{CONCLUSION}

The financial literacy variable has an effect on financial planning variables on students of Pesantren Luhur Malang and students of Pesantren Al-Barakah Malang. This indicates that the higher the financial knowledge and ability of students in managing finances, the wiser in making decisions related to finance. In these results in accordance with the theory of financial literacy that someone who has good financial knowledge will also have a good impact on financial decisions to be taken.

There are differences in financial literacy between the students of Pesantren Luhur Malang and Pesantren Al-Barakah Malang. Students of Pesantren Luhur Malang have a higher level of financial literacy than students of Pesantren Al-Barakah Malang. That is because students of Pesantren Luhur Malang periodically attend Islamic economic fiqh studies studied in Asybah Wan Nadhair written by Syech Imam Jalaluddin As Suyuthi such as debts, inheritance, rent, sale, purchase and so on. finance is also obtained from scientific halaqah activities carried out in the morning. While di Pesantren Al-Barakah Malang periodically also follows the study of Islamic economic jurisprudence which is studied in the book Fathurl Qorib by Syamsuddin Abu 'Abdillah Muhammad bin Qosim Al Ghozzi and his initial focusing on memorization of the Qur'an.
There are differences regarding financial planning between students of Pesantren Luhur Malang and students of Pesantren Al-Barakah Malang. Judging from the previous discussion that the understanding of financial literacy students of Pesantren Luhur Malang is higher compared to students of Pesantren AlBarakah Malang. This has an impact on decision making in financial planning, the higher the financial literacy a person has, the higher the financial planning he will make.

\section{References}

Akbar, A., August 2019. Seputar Perencanaan Keuangan Syariah. Finance Detik.com 23 .

URL: http://finance.detik.com/read/2013/07/24/070313/ 2312229/722/

Boon, T. H., Yee, H. S., Ting, H. W., 06 2011. Financial Literacy and Personal Financial Planning in Klang Valley Malaysia. International Journal of Economics and Management 5 (1), 149-168.

URL: http://www.ijem.upm.edu.my/vol5no1/bab08.pdf

Carpena, F., Cole, S., Shapiro, J., Zia, B., November 2011. Unpacking the Causal Chain of Financial Literacy. The World Bank Development Research Group 1.

URL: https://documents.worldbank.org/en/publication/ documents-reports/documentdetail/329301468322465624/ unpacking-the-causal-chain-of-financial-literacy DOI: $10.1596 / 1813-9450-579$

Dorimulu, P., 2003. Yang Menabur Yang Menuai. Investor 81.

Ghozali, I., 2009. Aplikasi Analisis Multivariate dengan Program SPSS.

Ghozie, P. H., 2019. Make It Happen (Buku Pintar Rencana Keuangan Untuk Mewujudkan Mimpi). PT.Gramedia Pustaka Utama, Jakarta.

Gujarati, D., 2009. Basic Econometrics. McGraw-Hill Irwin. URL: https : //books .google.co.id/books?id=611CPgAACAAJ

Kapoor, J. R., Dlabay, L. R., Hughes, R. J., 2014. Personal Finance. McGrawHill Higher Education.

URL: https://books.google.co.id/books?id=i3RzCgAAQBAJ

Margaretha, F., Pambudhi, R. A., November 2015. Tingkat Literasi Keuangan pada Mahasiswa S-1 Fakultas Ekonomi. JMK 17 (1), 76-85.

Otoritas Jasa Keuangan, November 2013. OJK Perkuat Upaya Inklusi dan Perluasan Akses Keuangan Melalui Literasi Keuangan. Majalah OJK Edisi November 2013.

URL: http://sikapiuangmu.ojk.go.id/public/content/files/ Majalah-0JK2.pdf

Otoritas Jasa Keuangan, November 2016. Survei Literasi Keuangan dan Inklusi.

Palameta, B., Nguyen, C., wai Hui, T. S., Gyarmati, D., ???? The link between financial confidence and financial outcomes among working-aged Canadians.

URL: $\quad$ http://www.srdc.org/media/199920/ fcac-full-report-on-financial-confidence-en.pdf

Robb, C. A., Woodyard, A. S., 2011. Financial Knowledge and Best Practice Behavior. Journal of Financial Counseling and Planning 205, 60-70. URL: https : //doi .org/10.1177/1090198112463021 DOI: $10.1177 / 1090198112463021$

Septiana, A., November 2017. Studi Fenomenologi: Model Literasi Keuangan Pondok Pesantren Madura. Et-Tijarie Jurnal Hukum dan Bisnis Syariah 4 (1).

URL: https://journal.trunojoyo.ac.id/ettijarie/article/ view/3898

Warsono, July 2010. Prinsip-Prinsip dan Praktik keuangan Pribadi. Journal of Science 13 (2).

Willis, L. E., November 2008. Against financial-literacy education. Iowa Law Review 94 (1), 197-285.

URL: https : //ssrn. com/abstract $=1105384$ 